\title{
Owning the customer franchise: The key to success
}

Received (in revised form): 10th May, 2000

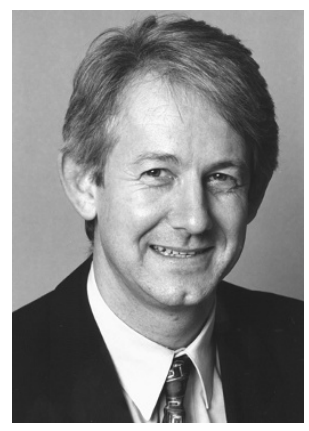

\section{Rob Macdermott}

is managing director of The Computing Group, leaders in customer relationship management and direct marketing solutions and services, and part of the WWAV Rapp Collins Group and part of Omnicom Worldwide.

Abstract This paper looks at the relationship whereby a customer allows a business to provide him with a service. It assesses the dynamism of the 'virtual customer relationship' and shows how the intelligent capture, analysis and management of customer data is the key to building a true knowledge and understanding of customers. Successful customer management then involves a multi-stage process of assembling and analysing dynamic data, using information from all sources to give a multi-faceted picture of an organisation's interactions with its customers. This data can then drive strategies that will lengthen an organisation's relationships with its customers and can increase the sales and term profitability of its business.

\section{INTRODUCTION}

The term 'customer franchise' was coined to describe the relationship whereby a customer allows a business to provide him or her with a service. For years, many companies have operated in the belief that this franchise is their right and that customers are not disposed to change from their existing providers unless they are very dissatisfied. In fact, even dissatisfied customers would remain with existing providers, either because the cost of changing supplier was prohibitive, there was no alternative, or they were unaware of their options.

Now the situation has changed. A revolution is underway which is affecting the rules of business. The exchange of goods or services for money can be viewed as a negotiation and the balance of power in this exchange depends on information. Until recently, businesses have had the upper hand because they had better information. The 20th century, however, saw the growth of a seemingly unlimited accessibility of information. Now in the 21st century, it is no longer the seller who has all of the information on products and competitive alternatives. The consumer of today has the ability to analyse, compare and choose from a wide field of competitive products and services. The consumer has the upper hand and is less likely to be driven by tradition and emotion.

Businesses, meanwhile, have responded to competitive threats and shareholder demand for return by cutting costs, by expanding mass marketing activity and by looking for product improvement or 
extension. As a result, despite spending millions on strengthening their efficiency, their processes and their market proposition, they have often lost sight of the 'key' to the customer relationship delivering value.

\section{THE SPREAD OF INFORMATION}

Information is everywhere. Advertising, consumer magazines, watchdog media programmes, and the Consumers

Association are among those bombarding people with knowledge about what is available and what is good value. In addition, more and more consumers are gaining electronic access to market products and services. On the Internet, they find a seemingly limitless range of price and product information. Although this is currently a 'small' percentage of buyers, this percentage will soon grow dramatically when access to the Internet becomes more widely available, via the television and mobile phones.

Information has given consumers choice and liberated them from stagnant or poor value suppliers. Customers are demanding value in return for their franchise. They have a clearer picture for themselves of what constitutes good value. They are becoming less loyal to their existing suppliers. They will no longer let the supplier define the value they are getting. Their expectations are higher and they are less tolerant of poor service. Businesses that continually ask the same questions, 'forget' about complaints, send duplicate or irrelevant offers, or commit the cardinal sin of mis-spelling a customer's name, are in danger of losing their customers to eager and predatory competitors. Customers do not want to take the time to repeat their explanations and will lose patience with organisations that fail to implement their wishes. If a requested service or product is not forthcoming, they will move their franchise.

\section{CUSTOMER SATISFACTION}

Although important, there is more to recognising and maintaining a valuable customer franchise than providing customer satisfaction. Several studies have shown that even customer satisfaction is not an automatic passport to customer loyalty. One study found that 90 per cent of defecting customers reported that they had been satisfied. ${ }^{1}$ It concluded that: 'satisfaction scores provide useful early warning of problems, but satisfied customers do not systematically buy more than dissatisfied ones'. Harvard Business School firm experts, Jones and Sasser $^{2}$ have carried out a number of studies analysing the relationship between customer satisfaction and customer loyalty in a number of sectors. Their work led them to characterise customers and their loyalty into four main groups:

— 'apostles' are those who are not only loyal but are so satisfied they recommend the provider to others

— 'mercenaries' are those who may switch service suppliers to obtain a lower price, even though they may be satisfied users

- 'hostages' are highly dissatisfied but have few or no alternatives

- 'terrorists' have alternatives and use them, and they also utilise every opportunity to convert others by expressing their dissatisfaction with a previous service provider.

One of the difficulties faced by most organisations is the consumer's reluctance to voice a complaint. British Airways discovered during research in the 1980s that as many as a third of its passengers were in some way unhappy with its 
service. ${ }^{3}$ Of these, 69 per cent never registered a complaint. Another 23 per cent complained at the time of discontent to the nearest BA employee. Only 8 per cent contacted customer relations where their complaints could be dealt with in a systematic way and captured in the company's customer information database. Regardless of how complaints were handled by the customer care frontline, British Airways was confronted with one of the most fundamental problems facing all organisations - getting people to complain. The effect of other new service initiatives, moreover, indicated that for every 1 per cent of additional dissatisfied passengers it could get to complain to its service office, it could win back $£ 200,000-£ 400,000$ in revenue from potential defectors.

\section{EXTENDING CUSTOMER RETENTION}

Retention cannot be taken for granted. Businesses need to be quick to recognise changes in customers' buying patterns and quick to earn loyalty through proactive action. MBNA, for example, one of the largest credit card issuers and service organisations in the United States, is currently developing an aggressively expansionist programme in countries beyond its first domain. In 1982, the company became concerned at the increase in the number of complaint letters it was receiving and a plan was implemented to increase active customer retention. One of the most simple and effective initiatives MBNA launched to extend customer loyalty was to call each cardholder who had stopped charging against the card. With one phone call, one in three cardholders immediately began using the card at, or above, the pre-lapse level. In addition, the company started gathering feedback from defecting customers, and used this information to correct service processes and develop new products. By 1990, MBNA's defection rate had fallen to one of the lowest in the industry, its profits had increased 16 times and it moved from 38th to fourth in its industry's market hierarchy.

The current generation is individualistic and positive about adopting change. This is reflected in people's working and personal lives. Jobs for life are a thing of the past, marriages last less and less, families are more fluid and individuals operate with greater personal awareness of self-interest.

Consumers want to be recognised as a power base of one. Customers' expectations are increasing as they shop around for the best deal; having access to more information and education about services and products allows them to be demanding. The individual consumer's rally cry is 'I consume, therefore I am'. Customers' demand for centricity is driving the negotiation for their franchise - they want to be served, each in their own special way. To survive competition in an open market, companies must respond by rediscovering the customer and by learning to treat each person based on their needs. The business leaders who recognise this will take action to exploit the value of the customer relationship. The winners will be those who continue to recognise, and deliver what the consumer wants, where they want it, how they want it and when they want it.

\section{IDENTIFYING THE INDIVIDUAL}

The driving question, therefore, is how do I get to know the individual? How do I find out how the individual wants to be treated? Obviously, it is impractical and impossible for today's large-scale national and international corporates to 
build actual intimacy with customers, nor would customers want it. Customers will be satisfied with 'virtual intimacy', or mass customisation, as long as they feel they are being treated as an individual and that there is a dialogue with the company.

Technology is the great enabler for 'virtual intimacy'. The consumer can set up and use his Egg account on the Internet, when and where it suits him; he can electronically access details of his on-line bank accounts. New distribution channels, including automatic telling machines (ATMs), Internet and e-mail, enable individuals to engage, at their convenience, in financial, communication or information transactions. Switching between providers is simpler, less personal and more efficient. New technology and new attitudes also mean that it is easier and less costly for new competitors to enter the market. The low entry cost into e-commerce has opened the door to a flood of start-ups offering customers rival products and services at attractively better value prices. The customer franchise is vulnerable to a new generation of unpredictable and aggressive predators with no respect for, or fear of, established boundaries or ground rules. For those determined to survive in the 21 st century, the real objective must be: how can I get my customer to want to remain my customer?

\section{UNDERSTANDING THE CUSTOMER}

The answer to this lies in building a true knowledge and understanding of the customer. In a 'virtual relationship', data are the conduit to customer insight; through analysis, data become knowledge and understanding. The process involves a multistage programme of assembling and analysing the right data, using information from all sources about an organisation's interactions with its customers.

The first stage is the most straightforward. Most companies now have an abundance of transactional data about their customers. Banks and insurers can track transfers, overdrafts, change in use and frequency, regularity of incoming funds, locations for credit cards etc. Telecommunication companies know the calling patterns, intensity and frequency of calls. Retailers with loyalty schemes can track purchasing behaviour and monitor products sold through the cash registers. Through their behaviour, as recorded by payment terminals and ATMs, customers are revealing exactly what they buy. By analysing and focusing on the real quantifiable behaviour of individuals, businesses can make decisions that are based on real facts, not intuition. These decisions will then have an impact on product development, marketing and preferred distribution channels. The customers benefit from better value, more personal offers; the business builds sustainable, profitable relationships with its customers.

Maintaining and managing these data, however, in order to maintain a sustainable customer relationship are costly. So, as well as understanding the behaviour of its customers, a business must also understand the value of each customer relationship to its bottom line. This often benefits from the addition of external socio- or geodemographic data to further enhance the information already collected on the customer. This will form a picture of the customer. Combined with derived data from tracking customer behaviour, the task of assessing individual customer value over time can then be progressed. Using data in this way allows the organisation to build an integrated customer view and can be used to identify which products and services may be attractive to this person. 


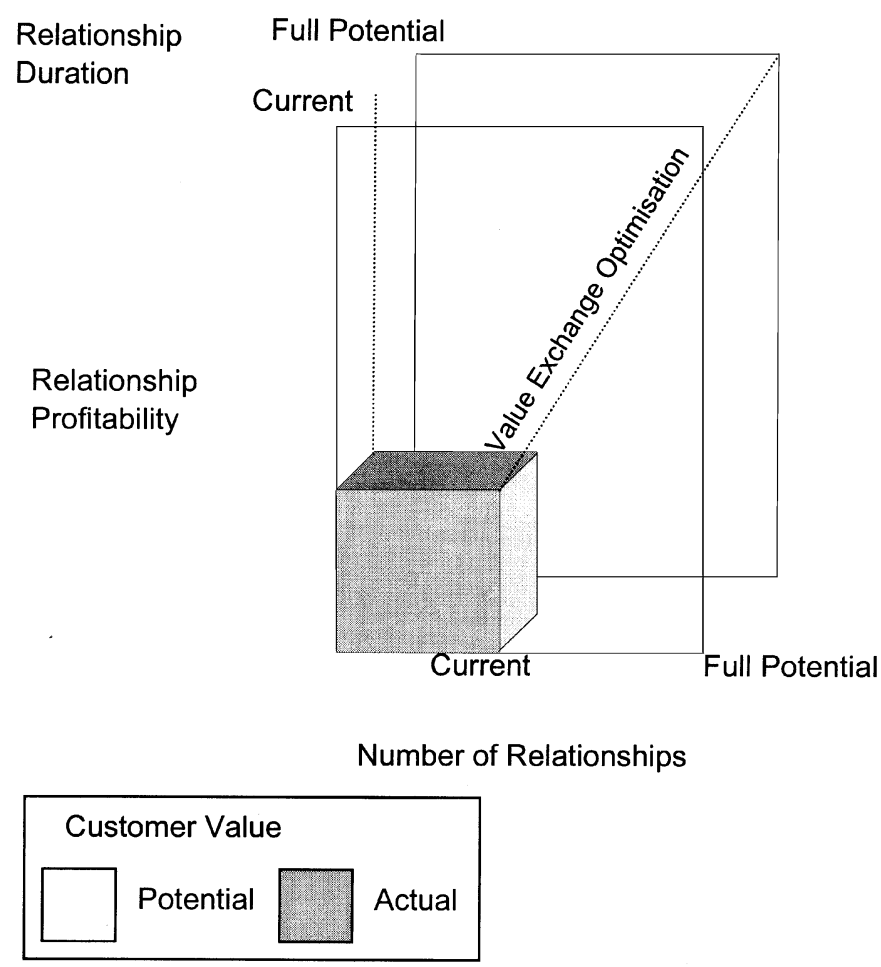

Figure 1 'The Service Profit Chain'

\section{POTENTIAL-BASED MARKETING}

Many marketing managers find it difficult to recognise that some customers are worth more than others and efforts to attract and please all potential customers can badly damage the bottom line. Potential-based marketing, or recognising the potential value of customers is key to profitable customer relationship marketing.

A good example of the value of potential-based marketing comes from an internal study prepared several years ago by $\mathrm{SMG}^{4}{ }^{4}$ a consultant to Swedbank. Upon examining customers' banking activities and comparing revenues and margins with costs, Swedbank found that 80 per cent of its customers were unprofitable. The 20 per cent of customers who were providing 100 per cent of the bank's profits were, however, nearly all dissatisfied with the service they were receiving. As a result, the bank set about investing capital in improvements targeted at the profitable customers. The customers it lost were some of the most unprofitable. Meanwhile, the profit-producing customers reacted positively to the new improved service they were receiving and began to increase their usage of the bank. Profits began to climb.

The goal of potential-based marketing is to identify the potential lifetime value of customers and to use that insight to drive strategies that will lengthen relationships with loyal customers, increase sales and increase the profitability of each sale opportunity. The general concept is illustrated in Figure 1.

Finding the best and loyal customers is key. Improving the profitability of the biggest loss-making customers, however, perhaps by driving them towards the competition is often overlooked. 


\section{RISK ANALYSIS}

Risk analysis is also a key component of customer evaluation. Providers of credit or insurance rely heavily on data analysis and customer segmentation for the running of their business. Insurers use demographic profile and personal experience to scale their rates, on the basis of how accident prone a policyholder might be. Further analysis of the behaviour of these segmented, risk assessed, customers can reveal surprising and potentially profitable anomalies. One leading insurer, for example, found that not all motorcycle owners or drivers previously cited for drunkenness represented high risks. For example, those with children under the age of 12 had distinctly lower accident rates than others. This enabled the insurer to accept applicants thought by others to have high-risk profiles, who could not get insurance elsewhere. The rates charged were of a higher premium, but were welcomed by these drivers, as they had been unable to obtain insurance with others. Given their actual behaviour patterns, these applicants represented high-margin business for the insurer.

Identifying missing information about a customer can also pay dividends for evaluating and benefiting from long-term relationships. Consider the individual made redundant from an executive position. She has been awarded a healthy redundancy payment and is looking for a loan to buy a car. The standard credit-referencing techniques at the bank note that she has no current income, and so perhaps a loan should be refused. More in-depth data analysis, however, shows the client to be a longstanding customer, who is in credit, has no outstanding loan and shows a high scoring low-risk customer profile. The business retains this customer franchise because it has understood her through information and given value to a relationship with her.

\section{CHANGING CUSTOMER BEHAVIOUR}

The customer franchise is not, however, a static asset. People change, market influences evolve and businesses need to understand and act on these developments. Using data to calculate the impact of, and generate improved profitability from, customer behaviour change is at the heart of successful customer relationship management. Data can be used to drive the management of customer change. Even small improvements in a customer's behaviour can lead to very significant profitability gains. A leading Canadian grocery chain found that expanding its customer base by 2 per cent with primary shoppers would increase the store's profitability by more than 45 per cent. Selling one more product to every customer would increase profits by more than 40 per cent. Reducing annual defection rates from 20 per cent to 10 per cent would increase customer relationships from an average of five to ten years and would more than double the lifetime value of each customer relationship. ${ }^{5}$

\section{CONCLUSION}

Continual analysis, modelling and refinement of the customer relationship improves the learning curve and helps businesses answer the perennial questions: Who are my best customers? Who are my best potential customers? Which customers should I lose? How do I respond to all their needs? We may have lost personal contact through mass communication and electronic media, but businesses can still find the answers to these questions; they can gain and hold the customer franchise by accessing, and fully exploiting customer data from all points of contact. The data that are employed in this kind of analysis provide an insight 
into individual customer relationships and they can be used to give the customers a service level that is appropriate and feels genuinely personal. The overall aim is to give customers the feeling that they are getting a personal service that is consistent at every interface in its relevance, its value and its individuality. The reward to the business will be reflected in the bottom line.

\section{References}

1 Heskett, Earl, Sasser and Schelsinger (1997) 'The service profit chain', p.84.

2 Klein and Sasser (1994) 'Using information systems to better serve the customer', HBS.

3 Based on work by Reichheld and Sasser referred to in Heskett, Earl, Sasser and Schelsinger (1997) 'The service profit chain', p. 106.

4 Based upon internal documentation prepared by SMG, a consultant to Swedbank.

5 Grant, A. W. H. and Schelsinger, L. A. (1995) 'Realise your customers' full profit potential' Harvard Business Review, Sept/Oct, pp. 59-72. 